\title{
Alley-Cropping Combinations for the Southeastern USA ${ }^{1}$
}

\author{
Sarah W. Workman, Samuel C. Allen, and Shibu Jose ${ }^{2}$
}

Alley cropping is an agroforestry practice where agricultural or horticultural crops are grown in the alleys between widely spaced rows of trees and/or shrubs. Alley cropping is a means to diversify and intensify production. By intercropping annual and perennial crops that yield varied products and revenues at different times, a landowner can more effectively use available space and resources. This can be particularly beneficial during the early years of timber or fruit tree production. In addition to the financial benefits, alley cropping also contributes to soil and water conservation, wildlife habitat and improved landscape aesthetics.

There are many possible combinations for alley-cropping systems. Perennials may vary from pines being grown for timber to pecans for nut production, to Christmas trees or other short rotation woody crops. Depending on objectives, the trees can be planted in single or multiple rows (Figure 1). The rows may include shrubs that produce berries, florals, wildlife food, or a number of other products. The interplanted annual crops may be even more diverse: pasture grasses for forage, cotton, soybeans, vegetables, ethnic herbs, for example, or various combinations of other crops.

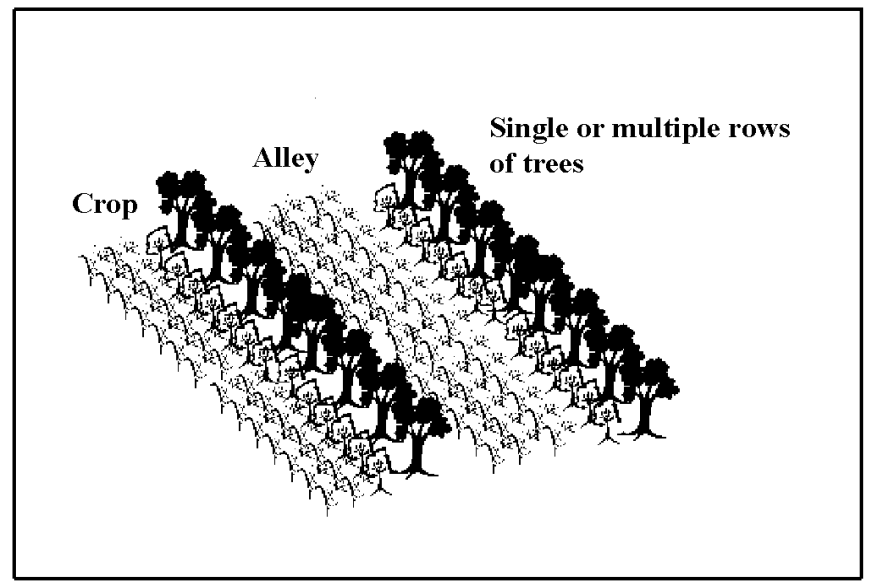

Figure 1. Alley cropping can combine a wide variety of tree and crop species, depending on the age of the trees, the light and water requirements of the crop, and the goals of the landowner.

This paper will provide readers with enough information to plan for alley-cropping on their land. It will describe several examples of alley cropping systems being developed in Florida. Also included is more specific information on the benefits and concerns that accompany this land use system as well as key design factors. Landowners interested in implementing alley-cropping practices should talk to their county extension and forestry professionals

1. This document, FOR 106, is one of a series through the Center for Subtropical Agroforestry (CSTAF), School of Forest Resources and Conservation, Institute of Food and Agricultural Sciences, University of Florida. First published August 2003. This publication was produced by the University of Florida with assistance from a grant from USDA/CSREES/IFAFS. For more information contact CSTAF, PO Box 110831, Gainesville, FL 32611, (352) 846-0146, UF Milton at (850) 983-5216 ext. 107, or http://CSTAF.ifas.ufl.edu. Please visit the EDIS Web site at http://edis.ifas.ufl.edu.

2. Sarah Workman, Visiting Assistant Professor, School of Forest Resources and Conservation and Center for Subtropical Agroforestry; Sam Allen, Postdoctoral Researcher; and Shibu Jose, Assistant Professor, School of Forest Resources and Conservation, Institute of Food and Agricultural Sciences, University of Florida, Gainesville, 32611.

The Institute of Food and Agricultural Sciences (IFAS) is an Equal Opportunity Institution authorized to provide research, educational information and other services only to individuals and institutions that function with non-discrimination with respect to race, creed, color, religion, age, disability, sex, sexual orientation, marital status, national origin, political opinions or affiliations. U.S. Department of Agriculture, Cooperative Extension Service, University of Florida, IFAS, Florida A. \& M. University Cooperative Extension Program, and Boards of County Commissioners Cooperating. Larry Arrington, Dean 
about the specific crops and markets that are appropriate for their location.

\section{Alley-Cropping Designs}

The most common alley-cropping designs utilize tree species that are already grown in plantations or orchards. Trees that have been used in alley-cropping designs in the U.S. include those listed in Table 1. Some pecan orchard owners, for example, practice this form of agroforestry by interplanting cover crops for grazing or hay production. Some owners also intercrop horticultural crops in the early orchard phase before nuts come into production. These measures can provide extra income from crops and also promote deeper rooting by the saplings. Planting early-maturing peach trees as an intercrop is another option.

Table 1. Trees Used in Agroforestry Designs.

\begin{tabular}{|c|c||}
\hline \hline Alder & Mimosa \\
\hline Ash & Oaks \\
\hline Basswood & $\begin{array}{c}\text { Ornamentals } \\
\text { (various) }\end{array}$ \\
\hline Birch & Paulownia \\
\hline Black Locust & Peach \\
\hline Chestnut & Pecan \\
\hline Christmas Conifers & Persimmon \\
\hline Cottowood & Pines \\
\hline Dogwood & Poplars \\
\hline Hazelnut & Sycamore \\
\hline Honey Locust & Walnut \\
\hline Maples & Willows \\
\hline \hline
\end{tabular}

Research by the University of Florida has demonstrated that yield of the alley crop is not affected by the presence of trees during the first few years of orchard establishment. A demonstration trial near Jay, Florida, includes pecan tree saplings planted in single rows at spacings of 35 feet between trees and 60 feet between rows. Cotton is grown in the alleys at 16 rows per alley. Similar tree-crop trials have been carried out with mature pecan and cotton (Figure 2), as well as loblolly pine and cotton, longleaf pine and cotton, and young pecan and peanut. The results are promising at this point, with similar crop yields from alley cropping and monoculture designs in young systems. As trees mature, however, significant interactions between the tree and crop component can be expected for light, water and nutrients. This may lead to reduced yields of the crop or tree species that should be accounted for in management plans.

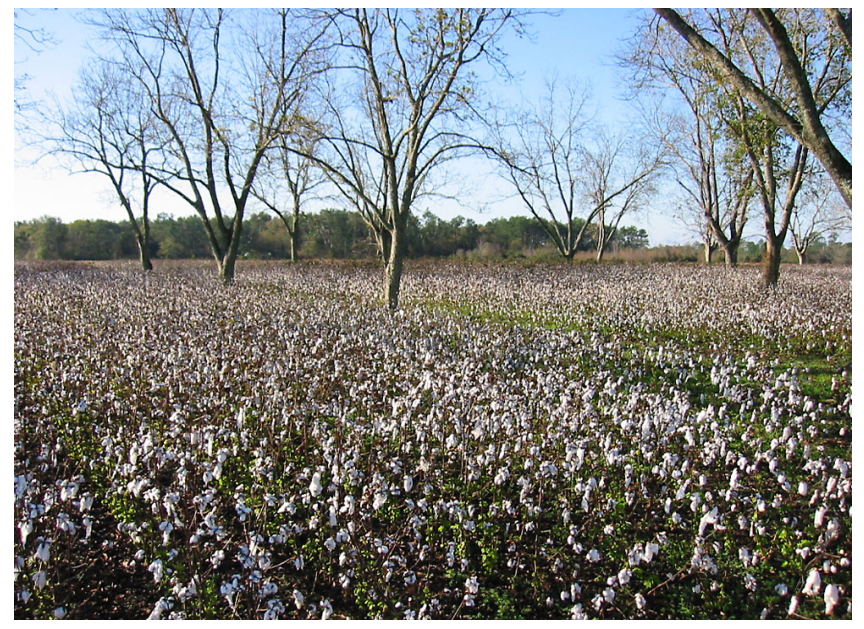

Figure 2. Pecan-cotton alley cropping near Jay, Florida. Credits: Photo by Shibu Jose

Innovative farmers have developed a variety of other alley-cropping designs and crop mixtures. For example, various combinations of chestnuts, persimmons, decorative willows, and ornamental foliage plants to produce greenery have been grown for farmers markets and other niche markets. Other combinations of fruit and nut trees or shrubs have been grown with various vegetables and herbs. In addition, some citrus growers cultivate horticultural crops between citrus seedlings during the first few years after grove establishment.

Alley cropping can be used for other purposes as well. For example, short rotation woody crops of fast growing tree species, harvested on 6-10 year rotations, can be combined with forage or row crops. Such designs may be used to produce fuelwood and fodder, as well as treat areas exposed to municipal sludge, wastewater, or livestock waste effluent. Plantings to enhance wildlife habitat (e.g., food and cover), can also be designed using appropriate plant species. 


\section{What Are the Benefits of Alley Cropping?}

Before changing current land use practices, farmers and forest owners should understand the benefits and concerns associated with intensive systems such as alley cropping. Benefits include:

Utilization of idle growing area. Since timber, nut, or fruit-bearing trees may take 20 years or more to mature, the space underneath can be used to grow row or other crops during the early stages of stand establishment. As long as crop management costs do not exceed revenues, the additional crops increase the short-term profitability of farm and tree stand management.

Diversification of income. Farmers who diversify by growing more than one type of crop are in a better position to weather the storms of market downturns or crop failure, since they have a variety of crops to market.

Diversification of harvest times. Field crops and trees mature at different times, thus providing periodic income over a longer stretch of time, rather than after a single harvest. Managers can also consider planting several crops a year and staggering harvest times.

Reduced soil erosion. Alley cropping is a good option for hillside farming and in areas prone to erosion, especially when tree and shrub rows are planted along contours. The presence of trees in annual crops, or crops between rows of young trees, generally helps to reduce soil erosion, increase water infiltration and improve nutrient retention. Tree roots help to hold the soil, and tree leaves and canopy provide a barrier against wind and rainfall impact.

Nutrient cycling. Leaves from trees provide green mulch that enhances soil fertility and benefits understory crops. In addition, crop fertilizers, often leached through the rooting zone, can be "recycled" by the roots of nearby trees and brought back to the surface when the trees shed their leaves, thus benefiting the crops with both nutrients and organic matter. In addition, nitrogen fixing cover crops can be used in the alleys to enhance soil fertility.

\section{What Are the Challenges and Disadvantages of Alley Cropping?}

Several concerns must be addressed when designing alley-cropping practices:

Timing of harvest. Crop production must be carefully timed to avoid interfering with tree crop harvest. In most cases, this is avoided because crops are grown mainly during the early years of tree establishment.

Markets for crops. It is always important before starting new crops to understand how and where those crops will be marketed. This is especially critical (and valuable) for niche markets such as herbs and specialty vegetables.

Chemical labeling restrictions. Care must be taken in applying pesticides and other agri-chemicals in alley cropping, to make sure that chemicals do not impact the other plants in the system and that they are not applied to agricultural or tree crops for which they are not approved.

Equipment handling. Alley cropping designs should be spaced widely enough to allow proper handling of mechanized equipment (e.g., tractor, planter, sprayer, picker), to avoid damage to equipment or trees and shrubs.

\section{Competition for light, water and nutrients.} The system should also be designed so that use of light, water and nutrients is optimized between trees and crops. Severe competition can reduce crop and/or tree growth and yields, particularly during dry periods. Competition may be reduced by proper variety selection, spatial arrangement, and timing of planting and harvest, as well as by disking, or pruning tree limbs or roots.

Weeds will need to be controlled in the tree rows for the first few years of seedling establishment. Mechanical methods should avoid unwanted damage to tree roots. Mulches or a good cover crop are viable alternatives for use around the trees. 


\section{Design Factors}

Species selection. Crop choices depend on the priorities for production and preferences of the landowner. Certain characteristics are desirable, however, for tree or shrub species planted in the rows: use for multiple products (timber, other wood or nontimber products), acceptable growth rate, deep roots with less surface rooting, leaf and canopy qualities (e.g., filtered light/shade and leaf decomposition rate) that do not hinder annual crop development, or value to wildlife. Row crops such as corn, soybeans, wheat, sorghum, or potatoes that need abundant light, will usually be shade limited by tree canopies except during the early years of tree establishment. Other crops that do well in shade can be planted under or closer to the trees.

\section{Crops}

Row crops such as corn, cotton, soybeans, wheat, barley, oats, sorghum, potatoes, peas

Warm season forages such as Pensacola bahiagrass, bermudagrass, creeping vigna

Cool season forages such as orchardgrass, ryegrass, desmodium, red, arrowleaf and white clover

Winter annuals such as crimson clover, hairy vetch

Horticultural crops such as watermelon, potatoes, pumpkins, strawberries, squash, raspberries

Specialty crops for medicinal (e.g., goldenseal), culinary (e.g., mushroom), or ornamental use (e.g., ferns)

Nutrient cycling. A chief design principle is to promote nutrient cycling within the production system. The deeper-rooted woody plants access nutrients below the annual crop roots and help recycle mineral elements. Trees also hold nutrients in their tissue during fallow periods, and thus conserve nutrients on site. Fresh leaf litter of trees combined with a winter crop of crimson clover or other legumes provides excellent green manure that can reduce chemical fertilizer needs of the next crop. Tree roots can be pruned, to reduce competition with the annual crop and to promote tree root growth in desired directions (e.g., laterally or deeper). This can be done with normal disking practices or with a sub-soiler blade to sever young tree or shrub roots.

Row spacing and alley width. The size of the machinery used to work the land must be considered to determine appropriate row spacing and alley width. Rows and alleys should be arranged to facilitate easy operation of the widest machinery without damage to machinery, crops or trees. In addition, the slope of the site and the need to protect against water and wind erosion should guide decisions as to the planting width of trees and crops. Moreover, light, nutrient, and moisture needs of alley crops will determine their compatibility and placement within the design. Utilizing the shady portion of the alley for one crop and the central portion for another, less shade-tolerant crop, could allow for simultaneous production of two or more crops.

In most cases, a spacing of 40 feet between rows will permit crop production for about five to ten years before the shade of trees begins to overlap. An 80 foot row spacing will likely permit production of row crops for up to 20 years. Likewise, if the alley crop is a warm season forage that is shade intolerant, or in an orchard for nuts or fruits, wide row spacing is desirable. If the crop is more shade tolerant, closer row spacing can be used. Closer row spacing would also be called for if timber or wood products were the primary products desired.

\section{Conclusion}

Alley-cropping systems in the southeastern U.S. are largely a new phenomenon, but offer considerable potential to innovative farmers and landowners. Properly managed, alley cropping can provide income at different time intervals for different markets. Alley designs can also make better use of the space available between trees and add protection and diversity to agricultural fields. Ultimately, landowners and managers can design production systems most suited to the labor and maintenance inputs they are willing to support. The bottom line is that alley cropping offers unique opportunities for generating income in a sustainable, conservation oriented manner. 